\title{
Natural Parasitism of Oebalus InsularisStal (Heteroptera: Pentatomidae) Eggs in Host Weeds Associated With Rice Cultivation in Panama
}

\author{
B. Zachrisson ${ }^{1}$ and P. Polanco ${ }^{2}$ \\ ${ }^{1}$ Instituto de Investigación Agropecuaria de Panamá (IDIAP), Ciudad del Saber, Edificio 611-612, Apartado \\ Postal 832-2758, Panamá, Panamá \\ ${ }^{2}$ Universidad de Panamá, Programa Centroamericano de Entomología, Ciudad Universitaria “Octavio Méndez \\ Pereira"; Panamá, Panamá
}

\begin{abstract}
The natural parasitism of Oebalus insularis eggs in the weed complex in areas adjacent to rice crops was evaluated. The high oviposition rate of this pest in Echinochloa colona and Echinochloa crus-pavonis favored the natural parasitism of Telenomus podisi. The host weeds serve as a natural reservoir of this egg parasitoid prior to the installation of crop production plots, promoting sustainability in the rice agroecosystem.

Keywords: Rice, weeds, Oebalus insularis, egg parasitoids, Platygastridae
\end{abstract}

\section{Introduction}

Oebalus insularis Stal, commonly known as the "rice stink bug," is one of the most important pests in rice cultivation in Panama and Central America [1], [2]. In addition, it is considered an invasive pest in the state of Florida (USA), where it has been present in all rice fields since 2007 [1], [3]. The damage is caused by second-instar nymphs and adults, which inoculate toxins and phytopathogens by sucking the grain content of the plant during the "milky" phenological state [4]. This process facilitates the entry of fungi from the genus Bipolaris Shoemaker, Fusarium Link, Neovossia Körnicke, Alternaria Nees, Curvularia Boedijn, and Nigrospora Zimmerman, among others [5], causing the symptomatology known as "grain staining." Therefore, the established relation between infestations is greater than 0.7 insects/panicle of $O$. insularis, and the infection rate recorded in the "milky" grain phase affects the crop yield [6], [7].

The host weeds distributed close to rice fields between sowing periods provide a reservoir of sucking insect species, suggesting the elimination of the pests through the application of herbicides to the weeds. This characteristic behavior of $O$. insularis is considered by some authors as a pest-survival strategy, allowing it to complete its biological cycle and reproduce in the absence of rice-producing areas [8], [9]. However, the presence of the $O$. insularis host weed complex also serves as a reservoir for parasitoids and predators, favoring the natural control of the sucking insect.Commercial rice plots in Panama have reported high rates of Telenomus podisi Ashmead parasitism [4]. However, the food and oviposition preference of $O$. insularis in the weed complex present in the areas near the rice plots is unknown, as is the rate of egg parasitism occurring these plants. Therefore, the present study determined the rate of natural parasitism of eggs of $O$. insularis in host weeds reported in areas near plots planted with rice.

\subsection{Description of the experimental area}

\section{Material and methods}

The experimental area is located in the town of Juan Hombrón, Coclé $\left(08^{\circ} 23^{\prime} 83^{\prime \prime} \mathrm{N}, 08^{\circ} 13^{\prime} 90^{\prime \prime} \mathrm{W}\right)$, Panama. The region has characteristics that define it as a "very humid tropical forest" (vhf-T) [10]. The climatic seasons were determined by the high rainfall recorded between May and October, which allows the rainy season to be differentiated from the dry season. However, in this study, the seasonality of the rainy and dry season did not follow the regular patterns recorded in the decade prior to 2010, a consequence of the natural phenomenon called "Climate Change." Temperature records $\left(32.8+1.2^{\circ} \mathrm{C}\right)$, annual rainfall $(5,000 \mathrm{~mm})$, and average relative humidity $(82.0+2.4 \%)$ during the evaluation period confirmed the climatic condition described.

\subsection{Experimental plots}

The areas adjacent to the rice crop (Oryza sativa $\mathrm{L}$. var. IDIAP-38), which was designated as the experimental area for the present study, were colonized by various weed species. At the beginning of May 2015 and 2016, the rice plot was used as a reference to delimit the evaluation area, which was sampled to identify the host weeds for $O$. insularis. Subsequently, the collection of material and recording of the experimental data were conductedduring weekly samplings in the months of June and July in each year evaluated. The area established for the sampling of the pest's host weeds corresponded to approximately 0.5 ha, where no herbicides were applied.

DOI: $10.9790 / 2380-1004010104 \quad$ www.iosrjournals.org $\quad 1 \mid$ Page


Natural parasitism of Oebalus insularis Stal (Heteroptera: Pentatomidae) eggs in host weeds ..

2.3 Experiment 1: Identification of host weeds and quantification of immature and adult Oebalus insularis

Samples of the host plant species, defined by the presence of all developmental stages of $O$. insularis, were carried out at the edge of the rice plot. The sampling unit, one of 50 randomly selected points, corresponded to $1 \mathrm{~m}^{2}$. The immature and adult $O$. insularissamples were collected and transferred to regulated climatic chambers that were maintained at a temperature of $28 \pm 1{ }^{\circ} \mathrm{C}$, relative humidity of $85.0 \pm 3.0 \%$, and photophase of 12 hours. Subsequently, the biological stages of $O$. insularis were separated and quantified, which allowed the average number of pests per plant in each developmental stageto be calculated. Nymphs hatching from nonparasitized eggs were maintained under controlled abiotic conditions until adulthood, allowing the taxonomic confirmation and sex determination of the insect. Species of host weeds were identified by specialists from the Herbarium of the University of Panama.

\subsection{Experiment 2: Determination of the parasitism rate of Oebalus insularis eggs per host plant}

The egg masses of $O$. insularis collected in the host weed complex were transferred to the laboratory, and individual eggs were placed in Petri dishes $(9.0 \times 1.5 \mathrm{~cm})$ on filter paper moistened with distilled water. Later, these Petri dishes were transferred to chambers regulated at a temperature of $28 \pm 1{ }^{\circ} \mathrm{C}$, relative humidity of $85.0 \pm 3.0 \%$, and photophase of 12 hours to await parasitoid emergence and proceed to species identification. The rate of egg parasitism was determined using the formula $\mathbf{P}$ [(number of parasitized eggs/total number of eggs collected) 100].

\subsection{Experimental design and statistical analysis}

The biological data from the $O$. insularis and from the parasitism of the eggs were subjected to the Hartley test to verify that these data followed a normal distribution. Therefore, the biological data were transformed by $\sqrt{x}+0.5$ and the rate of parasitism (\%) data, by arcsin $\sqrt{x}$. Subsequently, ANOVA $(P<0.05)$ was performed to determine if a significant difference existed among the biological parameters of the $O$. insularisin each host plant. The Duncan test $(\mathrm{P}<0.05)$ allowed us to infer the significant difference between the immature and adult mean numbers of $O$. insularis in each host plant species.

\section{Results}

The averages of the different $O$. insularis developmental stages were significantly higher in Echinochloa colona (L.) Link and Echinochloa crus-pavonis (Kunth) Schult. (Poaceae) (P <0.05) (Table 1). Lower averages of immature and adult $O$. insularis $(\mathrm{P}<0.05)$ (Table 1$)$ were recorded for the Cyperaceae species. Despite these results, the adaptation of the pest to Cyperus iria L. andCyperus rotundus L. was evidently a function of the development of the complete biological cycle of this sucking insect in the species of Cyperaceae. The mean number of $O$. insularisfemales per plant was higher than that recorded for males, a tendency observed in the plants reported as hosts $(\mathrm{P}<0.05)$ (Table 1).The mean number of eggs of $O$. insularis per plant was statistically higher in E. colona and E. crus-pavonis compared to Eleusine indica (L.) Gaerth, Ischaemum rugosum Salisb., and Paspalum virgatum L. (Poaceae) $(\mathrm{P}<0.05)$ (Table 1). However, the biological relation between $O$. insularis and the species Cyperus iria $\mathrm{L}$. andCyperus rotundus $\mathrm{L}$. could lead to an increase in the population of predators and parasitoids in the absence of rice cultivation (Table 1).

Table 1: Average number of immature (eggs and nymphs) and adult phases of Oebalus insularis in host plants associated with rice cultivation in Panama (2015-2016)

\begin{tabular}{|l|l|l|l|l|l|}
\hline Species & Family & $\begin{array}{l}\text { Average } \\
\text { Eggs/Plant }\end{array}$ & $\begin{array}{l}\text { Average } \\
\text { Nymphs/ Plant }\end{array}$ & $\begin{array}{l}\text { Average of Adults } \\
(\square) / \text { Plant }\end{array}$ & $\begin{array}{l}\text { Average of Adults } \\
(\square / \text { Plant }\end{array}$ \\
\hline Cyperus iria & Cyperaceae & $19.7 \pm 1.8 \mathbf{c}^{1}$ & $11.3 \pm 0.8 \mathbf{c}$ & $26.2 \pm 3.1 \mathbf{c}$ & $11.6 \pm 1.4 \mathbf{d}$ \\
\hline Cyperus rotundus & Cyperaceae & $14.2 \pm 2.9 \mathbf{d}$ & $9.7 \pm 1.4 \mathbf{c}$ & $30.1 \pm 1.6 \mathbf{d}$ & $14.4 \pm 1.3 \mathbf{e}$ \\
\hline Echinochloa colona & Poaceae & $85.7 \pm 6.2 \mathbf{a}$ & $73.6 \pm 3.1 \mathbf{a}$ & $64.2 \pm 3.9 \mathbf{a}$ & $34.7 \pm 3.1 \mathbf{a}$ \\
\hline Echinochloa crus-pavonis & Poaceae & $78.4 \pm 5.6 \mathbf{a}$ & $67.8 \pm 2.9 \mathbf{a}$ & $59.1 \pm 3.1 \mathbf{a}$ & $33.4 \pm 2.1 \mathbf{a}$ \\
\hline Eleusine indica & Poaceae & $29.2 \pm 2.6 \mathbf{b}$ & $33.4 \pm 4.0 \mathbf{b}$ & $41.9 \pm 4.8 \mathbf{b}$ & $20.5 \pm 3.8 \mathbf{b}$ \\
\hline Ischaemum rugosum & Poaceae & $28.2 \pm 3.1 \mathbf{b}$ & $30.9 \pm 3.7 \mathbf{~ b}$ & $39.3 \pm 1.9 \mathbf{b}$ & $17.2 \pm 1.6 \mathbf{c}$ \\
\hline Paspalum virgatum & Poaceae & $34.7 \pm 3.8 \mathbf{b}$ & $31.4 \pm 3.8 \mathbf{b}$ & $40.2 \pm 2.5 \mathbf{b}$ & $18.5 \pm 1.9 \mathbf{c}$ \\
\hline
\end{tabular}

${ }^{1}$ Means followed by the same letter in each column are not significantly differentby Duncan's test $(\mathrm{P}<0.05)$.

The $O$. insularis egg parasitism rate was significantly higher $(\mathrm{P}<0.05)$ in both species of Echinochloa $\mathrm{P}$. Beauv. (Poaceae), with notable parasitism by Te. podisi (Table 2). Regardless of the host plant species, parasitism by $T e$. podisi was significantly greater than that reported for Trissolcus basalis Wollaston $(\mathrm{P}<0.05)$ (Table 2$)$. 
Natural parasitism of Oebalus insularis Stal (Heteroptera: Pentatomidae) eggs in host weeds ..

Table 2: Rate of parasitism and parasitoid species for Oebalus insularis eggs in host plants associated with rice cultivation in Panama (2015-2016)

\begin{tabular}{|l|l|l|l|l|}
\hline Species & Family & $\begin{array}{l}\text { Rate } \\
\text { parasitism }(\%)\end{array}$ & $\begin{array}{l}\text { Rate of parasitism/ } \\
\text { Telenomus podisi }(\%)\end{array}$ & $\begin{array}{l}\text { Parasitism } \\
\text { Trissolcus basalis }(\%)\end{array}$ \\
\hline Cyperus iria & Cyperaceae & $14.2 \mathbf{e}^{1}$ & $89.4 \mathbf{b}$ & $10.6 \mathbf{c}$ \\
\hline Cyperus rotundus & Cyperaceae & $9.8 \mathbf{f}$ & $81.2 \mathbf{c}$ & $18.8 \mathbf{b}$ \\
\hline Echinochloa colona & Poaceae & $92.6 \mathbf{a}$ & $96.4 \mathbf{a}$ & $3.6 \mathbf{e}$ \\
\hline Echinoclhoa crus-pavonis & Poaceae & $78.3 \mathbf{b}$ & $82.4 \mathbf{c}$ & $17.6 \mathbf{b}$ \\
\hline Eleusine indica & Poaceae & $23.1 \mathbf{d}$ & $78.3 \mathbf{d}$ & $21.7 \mathbf{a}$ \\
\hline Ischaemun rugosum & Poaceae & $21.9 \mathbf{d}$ & $82.6 \mathbf{c}$ & $17.4 \mathbf{b}$ \\
\hline Paspalum virgatum & Poaceae & $38.9 \mathbf{c}$ & $86.1 \mathbf{b}$ & $13.9 \mathbf{d}$ \\
\hline
\end{tabular}

${ }^{1}$ Means followed by the same letter in each column are not significantly different by Duncan's test $(\mathrm{P}<0.05)$.

\section{Discussion}

The conservation of host weeds that serve as reservoirs for phytophagous insects forO. insularisin areas surrounding rice crops promotes populations of Oebalusspp., which can colonize the production plots after planting [11], [12]. Therefore, several authors recommend the elimination of these weeds by the application of herbicides [9], [11], [12]. However, consideration of the "pest-weed-parasitoid" trophic interaction shows that the hostweed complex is not limited to harboring phytophagous insect species at different stages of their biological development but also favors the survival of beneficial insects [14]. Therefore, the conservationof the egg parasitoids Te. podisi and Tr. basalis, which are considered key mortality factors of $O$. insularis [13] and are found in the host weed complex near the rice crop, reduce the pest population [13].

The adaptation of phytophagous Pentatomidae insectsto a wide range of host plant species is a function of several variables, including morphological, physiological, and behavioral factors [9]. The biological and reproductive performance of these sucking insect species depends mainly on the nutrient quality, presence of secondary metabolites, and plant architecture, among other aspects [8], [9], [11], [12]. Some authors confirmed the adaptation of Oebalus pugnax Fabricius to different host weeds in the areas surrounding this crop in Mississippi (USA), highlighting E. colona, Paspalum dilatatum Poir, and Paspalum notatum Fluge. The results presented confirm the nutritional versatility of the OebalusStal complex to various species of host plants belonging to the families Poaceae and Cyperaceae, especially the genus Echinochloa [14]. Biological studies under controlled abiotic conditions confirmed the efficient biological and reproductive performance of $O$. insulariswhenE. colonawas the food source [13]. Feeding and breeding Oebalus species depends, among other factors, on the phenology of the host plants, which is related to the nutrient concentration [12]. The oviposition behavior of the Pentatomidae species is conditioned by the chemical and physical variables of the host plant, specifically the nutritional quality, which is reflected in the reproductive capacity of this insect (Fig. 1) [15]. Thus, the variability in the mean number of $O$. insularis eggs per host plant recorded for species of Cyperaceae and Poaceae (Table 1) is explained. This trophic interaction could be affected by the increase in temperature due to the influence of this abiotic factor on the biological and reproductive development of the pest [12], [16].

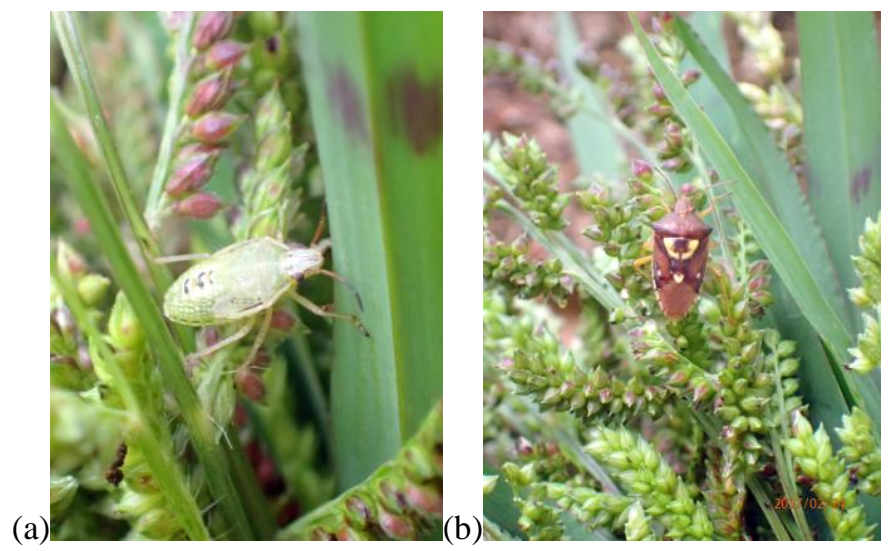

Figure 1: Nymph (a) and adult (b) phases of Oebalus insularis feeding on Echinochloa colona in weed plots adjoining the rice crop

The relation between the reproductive capacity of $O$. insularis and the secondary metabolites of host plants may also influence the average number of eggs recorded for each weed species. Therefore, the parasitism rate of eggs is directly related to the nutritional quality of the host plant species [13]. This explains the high rates 
Natural parasitism of Oebalus insularis Stal (Heteroptera: Pentatomidae) eggs in host weeds ..

of parasitism recorded in speciesE. colona and E. crus-pavoni. Regardless of the strongly significant differences between the rate of parasitism and host plants, Te. podisi was the most prevalent species in the areas adjacent to the rice plots. Competition for the same ecological niche and adaptive capacity are factors that may also explain these results [13]. The new biotic associations reported in the present study suggest a rethinking of integrated pest management programs in rice cultivation. In addition, the adaptive capacity of Te. podisi as a natural alternative for the management of the Pentatomidae species complex in the rice agroecosystem has not been discounted [17].

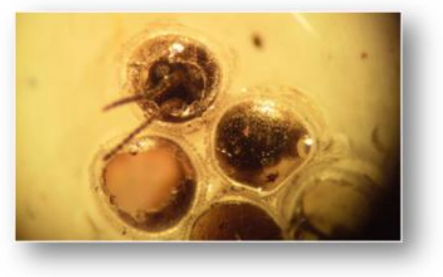

Figure 2: Adult Telenomus podisi emerging from an egg of Oebalus insularis that was oviposited in Echinochloa colona in weed plots adjoining the rice crops

\section{Conclusions}

The conservation of host weeds for $O$. insularis in areasnear rice crops favored the high rate of natural control byTe. podisi, a condition that can be considered a sustainable alternative for pest management. Therefore, the role of host plants as reservoirs of the egg parasitoids of this sucking insect species is highlighted during the establishment of production plots of this agricultural item. The "pest-parasitoid-host plant" interaction is an important dynamic process, which should strengthen integrated pest management (IPM) and integrated crop management (ICM) programs.

\section{Acknowledgments}

The National Secretariat of Science, Technology and Innovation (SENACYT) is acknowledged for the financial support offered through the National Research System (SNI) of Panama.

\section{References}

[1]. R. Cherry, and G. Nuesly, Establishment of a new stink bug pest, Oebalus insularis (Hemiptera: Pentatomidae), in Florida rice. Florida Entomologist, 93, 2010, 291-293.

[2]. P.G. Rodriguez, D. Navas, E. Medianero, and R. Chang, Cuantificación del daño oasionado por Oebalus insularis (Heteropetra: Pentatomidae) en el cultivo del arroz (Oryzica-1) en Panamá. Revista Colombiana de Entomología, 32, 2006, $131-135$.

[3]. R.A. Panizzi, Growing problems with stink bugs (Hemiptera: Heteroptera: Pentatomidae): Species invasive to the U.S. and potential neotropical invaders. American Entomologist, 61(4), 2015, 223-233.

[4]. B.A. Zachrisson, and O. Martínez, Bioecologia de Telenomus podisi (Ashmead) y Trissolcus basalis (Wollaston) (Himenoptera: Scelionidae), parasitoides oófagos de Oebalus insularis (Kulghast) (Heteroptera: Pentatomidae). Tecnociencia, 13, 65-76.

[5]. L.E. Datnoff, T.A. Kucharek, and K.L. Pernezny, Some common diseases of rice in Florida, Circular 1242, IFAS Extension University of Florida, Florida, FL, 1999, 1-5

[6]. E. Ferreira, J.A.F. and Barrigossi, Produção e qualidade do grão irrigado infestado por adultos de percevejo-das-panículas. Pesquisa Agropecuária Brasileira, 41, 2006, 1083-1091.

[7]. L.E. Vivas, and A. Notz, Determinación del umbral y nivel de daño económico del chinche vaneadora del arroz, sobre la variedad cimarrón en Calabozo estado de Guárico, Venezuela. Agronomía Tropical, 60, 2010, 271-281.

[8]. G.A. Awni, J. Gore, D. Cook, J.A. Bond, F.R. Musser, and C.A. Adams, Host preference and suitability of grasses for Oebalus pugnax. Entomologia Experimentalis et Applicata, 152, 2014, 127-134.

[9]. L.F. Smaniotto, and R.A. Panizzi, Interactions of selected species of stink bugs (Hemiptera: Heteroptera: Pentatomidae) from leguminoes crops with plants in the neotropics. Florida Entomologist, 98(1), 2015, 7-17.

[10]. L.R. Holdridge, Life Zone Ecology (CATIE-IICA, Tropical Science Center. San José, CR, 1966.)

[11]. M.P.B. Pasini, A.D.C. Lúcio, and A.L.P. Ribeiro. Populations of phytophagous bugs influenced by crop background and wild plants. Amazonian Journal of Agricultural and Environmental Science, 38(4), 2015, 410-417.

[12]. G.A. Awni, J. Gore, D. Cook, F.Musser, and J. Bond. Seasonal abundance and phenology of Oebalus pugnax (Hemiptera: Pentatomidae) on graminaceous hosts in the delta región of Mississippi. Environmental Entomology, 44(4), 2015, 931-938.

[13]. B. Zachrisson, V. Costa, and J. Bernal. 2014. Incidencia natural de parasitoides de huevos de Oebalus insularis Stal. (Heteroptera: Pentatomidae) en Panamá. IDESIA, 32(2), 2014, 119-121.

[14]. B. Zachrisson; P. Polanco, and O.Martínez, Desempeño biológico y reproductivo de Oebalus insularis Stal (Hemiptera: Pentatomidae), en diferentes plantas hospedantes. Revista de Protección Vegetal, 29(2), 77-81.

[15]. A.R. Panizzi, and F.A.C. Silva, Insetos sugadores de sementes (Hetroptera), in A.R.Panizzi and J.R.P.Parra (Eds.), Bioecología e nutrição de insetos, 1 (Brasilia: EMBRAPA, 2009) 465-522.

[16]. K. Kiritani, Predicting impacts of global warning on population dynamics and distribution of arthropods in Japan. Population Ecology, 48, 2006, 5-12

[17]. B. Zachrisson, P. Osorio, P. Polanco, and I. Camargo. Parasitismo natural de huevos del complejo de especies de Pentatomidae (Heteroptera), en el agroecosistema arroz en Panamá. Puente Biológico, 8, 2016, 1-7. 